\title{
Smíšený mód a online dotazování: mezinárodní praxe a tuzemská připravenost na implementaci ${ }^{1}$
}

\section{Mixed-Mode Designs and Computer-Assisted Web Interviewing in International and Czech Social Surveys}

\author{
Barbora Hubatková, Martin Lakomý
}

\begin{abstract}
The cost of interviewer-administered data collection (CAPI, CATI) has been gradually rising, while response rates have been declining over time. This situation has led to the domination of online data collection (CAWI), which tends to suffer from poor population coverage and even lower response rates. This could be overcome by combining this method with another mode of data collection. This paper aims to summarise the main principles of mixed-mode design, its implementation in major international surveys, and the first results of a project testing the feasibility of the push-to-web mixed-mode design in the Czech context. The results illustrate that together, unequal distribution of technological skills and willingness to participate distort the recruitment of random samples for CAWI towards middle-aged and more educated respondents. The mixed-mode design - together with the described components - has the potential to better involve underrepresented groups, while it is essential to follow the rules for achieving comparable answers across modes and devices. Finally, we emphasize the need to disseminate findings to researchers and other users of survey data, as the use of mixed-mode design has been rapidly increasing.
\end{abstract}

KEYWORDS mixed-mode design, social surveys, CAWI, the Czech Republic, methodological research

\section{Úvod}

Mezi hlavní problémy, s nimiž se v České republice i v zahraničí v současnosti potýká oblast výběrových šetření, se řadí především klesající návratnost a rostoucí finanční náklady. Potenciální respondenti jsou z mnoha důvodů (např. nezájem, nedostatek času, přezkoumání populace či obavy o soukromí) stále méně ochotni na dotazníkových výzkumech participovat (Couper 2017, s. 121; Krejčí 2008). To vede k navýšení nákladů na šetření, nebot' více prostředků je nezbytné vynakládat na kontaktování a rekrutaci respondentů i na práci tazatelů

Sociálni studia / Social Studies 1/2021. S. 13-33. ISSN 1214-813X.

1 Práce na tomto článku byla podpořena Technologickou agenturou ČR v rámci programu ÉTA, projekt „Vývoj multimode sběru dat a zavádění tohoto typu dotazování v oblasti populačního, sociologického a marketingového výzkumu“ (č. TL02000152). 
(Couper 2017, s. 121; Tourangeau 2017, s. 115). Tato situace, společně s rostoucí dostupností technologií, ústí ve stále rozšířenější používání dotazování online (tzv. CAWI, computer-assisted web interviewing), které je typicky chápáno jako levnější, flexibilnější, rychlejší a mnohdy i uživatelsky zajímavější než tradiční metody (de Leeuw a Hox 2011; Dillman et al. 2014; Tourangeau 2017). Navzdory výhodám však CAWI trpí nízkou návratností, omezenou dostupností opor výběru a nedostatečným pokrytím obecné populace (Couper 2017; Tourangeau 2017). To se může odrazit v kvalitě výsledných dat, jež mohou trpět různými druhy zkreslení a chyb (Bethlehem a Biffignandi 2011, s. 99-102).

Pokusem o překročení limitů CAWI i ostatních módů sběru dat (návratnost, pokrytí, cena, rychlost) je jejich kombinování do tzv. smíšeného módu. ${ }^{2}$ Ačkoli kombinace mohou být v principu různé, obvyklým elementem současných designů se stává právě dotazování po internetu (Couper 2017, s. 127; Dillman et al. 2014, s. 401; Lynn 2020, s. 19), nebot' představuje jakousi „přemost'ovací“ fázi mezi tradičními postupy sběru dat a úplným přechodem do online prostředí očekávaným v blízké budoucnosti (Toepoel a Lugtig 2015, s. 157).

Účelem tohoto textu je v první řadě představit aktuální praxi využívání (tohoto typu) smíšeného módu ve vybraných mezinárodních výzkumných infrastrukturách, s jejichž daty česká sociálněvědní obec často pracuje. V návaznosti na tento přehled pak diskutujeme situaci v ČR a tuzemskou připravenost $\mathrm{k}$ implementaci smíšeného módu zahrnujícího online dotazování (s nímž bude nutné počítat mj. v kontextu zapojení ČR právě v těchto infrastrukturách). Tuto připravenost následně popisujeme prostřednictvím dílčích výsledků vlastního metodologického projektu. Zde se přitom soustředíme zejména na možnosti a limity dotazování online, které (1) tvoří stěžejní část aktuálních smíšených designů a současně, (2) ač není v tuzemsku novinkou, je na rozdíl od „tradičních“ módů v české (publikované) metodologické diskusi spíše na pokraji zájmu. Chybějící empirická zjištění jsou problémem pro rozvoj metody v našem prostředí, jelikož se úspěšnost různých technik sběru dat, jejich prvků či kombinací v různých zemích typicky liší (např. Martin 2011, s. 21-22; Villar a Fitzgerald 2017, s. 269270). Tento fakt poukazuje na omezenou aplikovatelnost zahraničních poznatků a podtrhuje potřebu testování na národní úrovni.

Článek věnuje pozornost nejprve představení smíšeného módu a online dotazování. Teorie se v dotýkáme spíše v užším záběru ${ }^{3}$ a s důrazem na nejnovější poznatky. Následně shrnujeme aktuální praxi ve vybraných mezinárodních výzkumných infrastrukturách. Poté se věnujeme současné situaci v ČR a diskutujeme připravenost na implementaci smíšeného módu s online elementem, a to primárně prostřednictvím posouzení prripravenosti českého terénu na CAWI. V závěru poskytujeme syntézu poznatků a nabízíme širší diskusi vývoje v blízké budoucnosti. Celý text pojednává o situaci v prostředí sběru dat pro akademické

2 Účelem je přitom využití silných stránek každého z použitých módů. Potenciálním problémem smíšeného módu je možný vliv módu na odpovídání, ten je - s výjimkou citlivých otázek - nicméně malý až zanedbatelný (Callegaro et al. 2015, s. 38; Hox et al. 2017, s. 514).

3 Pro zevrubný, česky psaný teoretický přehled tak čtenáře odkazujeme na stat' Martina Buchtíka (Buchtík 2012), která představuje většinu stěžejných témat, zavádí českou terminologii (vč. termínu „smíšený mód“) a poskytuje dobrý vhled to problematiky smíšeného módu. 
instituce, jelikož výzkum komerční se liší požadavky na kvalitu dat, využíváním kvótních výběrů, mírou systematického testování, publikačními výsledky apod.

\section{Základní charakteristiky a terminologie smíšeného módu}

Smíšený mód, multimode nebo také mixed-mode jsou termíny označující kombinaci dvou či více módů ve výběrových šetřeních. Mezi hlavní módy typicky řadíme mód osobní, tzv. tváří v tvář (vyplnění dotazníku s tazatelem na počítači nebo na papíře - CAPI, PAPI), telefonický (vyplnění dotazníku s tazatelem po telefonu - CATI) a samovyplňovací (tedy vyplnění papírového nebo elektronického dotazníku př́mo respondentem - PAP, CASI, CAWI). Pojem smíšený mód je v literatuře i praxi chápán poměrně volně 4 a může odkazovat jak $\mathrm{k}$ fázi sběru dat, tak i k fázi oslovení respondentů. Při samotném sběru dat se mưže mód lišit napříc vlnami u longitudinálních šetření (de Leeuw a Hox 2011), napříč zeměmi v mezinárodních studiích (de Leeuw a Toepoel 2018) a v rámci jednoho sběru dat, přičemž zde se může jednat o smíšený mód „,v rámci respondentů“ (kdy každý respondent vyplňuje dotazník vícero módy), nebo „např́íč respondenty“ (kdy se jedna část vzorku celého šetření účastní jiným módem než část druhá). Tyto různé varianty mohou být navíc různě kombinovány (de Leeuw a Hox 2011). V tomto článku se zaměřujeme především na smíšený mód v rámci sběru dat napříč respondenty; od jiných typů však - kvůli jejich časté propojenosti - nelze v diskusi zcela odhlédnout.

Implementace smíšeného módu např́ič respondenty má dvě hlavní podoby - souběžnou a sekvenční (následnou). V souběžném designu (tj. sběr dat dvěma či více módy probíhá paralelně) se použitý mód sběru dat řídí preferencemi respondentů, dostupnými kontaktními údaji, národními specifiky či (předpokládanou) technickou vybaveností respondentů (de Leeuw a Toepoel 2018, s. 53-54; de Leeuw et al. 2018, s. 394). V sekvenčním designu je naopak jeden mód hlavní, zatímco druhý slouží k následnému dosběru dat ve vybraných subpopulacích, které byly v rámci hlavního módu podreprezentovány. Účelem obou designů je jak zlepšení reprezentativity, tak zvýšení návratnosti (de Leeuw a Toepoel 2018, s. 52-53). Sekvenční design obvykle dosahuje lepších výsledků (např. vyšší návratnosti); jeho výhodou je také možnost sesbírat velkou část dat prostřednictvím levnějšího módu (de Leeuw a Toepoel 2018; Tourangeau 2017).

\section{Dotazování online jako element smíšeného módu}

Primární motivací pro kombinování módů je překonání nedostatků jednotlivých technik za účelem - jak shrnují např. Dillman et al. (2014, s. 401-403) - dosažení nižších nákladů, větší rychlosti sběru dat, lepšího pokrytí populací, vyšší návratnosti a snížení různých druhů chyb měření. Z metodologického hlediska se striktně nejedná o novinku ( $\mathrm{k}$ historii stručně

4 Ačkoli v poslední době dochází k jisté terminologické cizelaci. Projekt MIMOD, o němž bude řeč dále $\mathrm{v}$ textu, např́klad rozlišuje mezi mixed- a multi- módem, přičemž mixed-mode je chápán jako nasazení několika módů pro sběr dat napříč respondenty, zatímco multimód se vztahuje k situaci, kdy se několika módy šetření účastní všichni respondenti. 
Buchtík 2012), explicitní zájem o smíšený mód je však spíše záležitostí poslední doby a úzce se pojí s nástupem, možnostmi i limity online dotazování (de Leeuw a Toepoel 2018, s. 51). CAWI je typicky chápáno jako levnější, rychlejší a praktičtější než jiné módy (Bethlehem a Biffignandi 2011, s. 45-47; Couper 2017, s. 131; Dillman et al. 2014, s. 301), protože má možnost plně využít současných technologií, není vázáno na geografickou lokalitu, je flexibilní (pro výzkumníky i respondenty), umožňuje sběr a analýzu dat v reálném čase a využití komplexních filtrů, videí, obrázků a grafických prvků, umožňuje automatizaci dílčích úkonů (např. přechod na další stranu dotazníku), netrpí vlivem tazatele a může být vhodným nástrojem pro dotazování citlivých otázek (Couper 2017, s. 131; de Leeuw a Toepoel 2018, s. 51; Smyth a Pearson 2011).

Na druhou stranu se online dotazování potýká s řadou problémů, které často neumožňují jeho využití jako jediný mód sběru dat. ${ }^{5}$ Dvěma hlavními problémy jsou poměrně nízká návratnost (literatura uvádí, že ve srovnání s tradičními módy může být návratnost nižší o 11 až 13 \% [Couper 2017, s. 131; Tourangeau 2017, s. 119]) a nedostatečné pokrytí obecné populace, vč. chybějící opory výběru respondentů ${ }^{6}$ (Callegaro et al. 2015; Couper 2017; de Leeuw a Toepoel 2018; de Leeuw et al. 2018). CAWI se také zdá být obzvláště náchylné k různým druhům tzv. satisficingu, tj. chování, kdy respondenti dotazníku nevěnují dostatečnou pozornost (Conrad et al. 2017, s. 45). Typickým př́kladem je př́liš rychlé vyplnění, častá volba odpovědi „nevím“, výběr první nebo poslední položky ve výčtu odpovědí, výběr odpovědí pod sebou nebo diagonálně v bateriích anebo přímo uvádění nepravdivých informací (Conrad et al. 2017, s. 47-48; Struminskaya et al. 2015, s. 263). Navíc řada výhod CAWI může být současně jeho nevýhodami: prvky jako automatizovaný průchod dotazníkem, výzvy a hlášení, vynucené odpovídání nebo ukazatel průběhu mohou respondenty za různých podmínek motivovat i odradit (např. Gummer a Roßmann 2015; Selkälä a Couper 2018). Stejně tak grafické prvky, zejména obrázky, mohou ústit v chybu měření (Bethlehem a Biffignandi 2011, s. 199-200; Smyth a Pearson 2011).

Dalším potenciálně problematickým parametrem CAWI je skutečnost, že respondenti mohou online dotazníky vyplnit na celé řadě zařízení, od osobních počítačů po chytré telefony různých velikostí a technických parametrů (displej, operační systém, personalizované nastavení). To ve výsledku může vést $\mathrm{k}$ chybě měření, nebot' dotazník se může různým respondentům zobrazovat různě (Callegaro et al. 2015, s. 199-201; de Leeuw a Toepoel 2018, s. 56-57; Dillman et al. 2014, s. 302; Struminskaya et al. 2015, s. 262-263); a paradoxně i ke konzervativnějšímu přístupu při designu dotazníku (tj. nedochází k plnému využití potenciálu CAWI). Nová zařízení s přístupem k internetu jsou zároveň mobilnější, což zvyšuje pravděpodobnost, že se respondenti při vyplňování dotazníku budou věnovat jiným činnostem (tzv. multitasking) nebo se budou nacházet v přítomnosti jiných osob; obojí se opět může nepř́iznivě podepsat na kvalitě dat (Bosnjak et al. 2018, s. 63; Couper a Peterson 2017 , s. 361; de Leeuw a Toepoel 2018, s. 57). Nakolik může smíšený mód tyto problémy reálně

5 Zejména tedy v reprezentativních šetřeních. Poměrně rozšiřrené online panely tyto problémy reflektují pouze omezeně, nejčastěji kvótní povahou výběru a kontrolou satisficingu.

6 Nelze např. náhodně generovat e-mailové adresy, tak jako lze náhodně generovat telefonní čísla prostřednictvím tzv. random digit dialing neboli RDD. 
řešit, prozatím zůstává předmětem testování. Využitelnost smíšeného módu založeného na CAWI (a následně samostatně stojícího CAWI) by se ale měla zvyšovat s růstem ICT vybavenosti a gramotnosti různých částí populace i s vývojem technických parametrů nových zařízení včetně rychlejšího přenosu dat (Callegaro et al. 2015, s. 204-205).

V následující části textu se zaměříme na současnou praxi smíšeného módu a dosavadní poznatky o jeho fungování v širším evropském kontextu. Shrneme nejpoužívanější formy smíšeného módu ve velkých šetřeních a současně proměnu povahy dat pro jejich uživatele.

\section{Smíšený mód v mezinárodních šetřeních}

Ačkoli využívání smíšeného módu je v mezinárodní praxi stále rozšířenější, víceméně chybí ucelenější přehled konkrétní implementace, fungování, návratnosti a jiných charakteristik tohoto designu. Účelem následující kapitoly je poskytnout alespoň základní přehled pro největši mezinárodní výzkumné infrastruktury, s jejichž daty čeští sociální vědci běžně pracují, ačkoli postup sběru těchto dat (či mezinárodní rozdíly v použitých módech) jim nemusí být nutně známý. Většinou tedy ani neuvažují o práci s módem sběru např. jako s kontrolní proměnnou kvůli potenciálu módu ovlivnit odpovědi především na citlivé otázky (Callegaro et al. 2015, s. 38; Chylíková 2011, s. 193-194). Konkrétně shrneme současnou i nedávnou praxi v šetřeních European Social Survey (ESS), European Values Study (EVS), Survey of Health, Ageing and Retirement in Europe (SHARE), International Social Survey Programme (ISSP), Generations and Gender Survey (GGS) a ve vybraných šetřeních sbíraných v rámci Evropského statistického systému. Všechna tato výběrová šetření - do různé míry - reprezentují různé typy smíšeného módu, o nichž byla řeč výše, tj. smíšený mód v čase, v rozdílech mezi zeměmi, nebo v rámci jednoho sběru dat. Zároveň je ve všech variantách zřetelná narůstající role online dotazování.

\section{Projekt MIMOD}

Jeden z mála systematičtějších přehledů aktuální praxe využívání smíšeného módu v mezinárodním kontextu lze nalézt mezi výstupy z projektu Mixed Mode Designs in Social Surveys (akronym MIMOD, řešení 2017-2019). ${ }^{7}$ Jedna $\mathrm{z}$ jeho pěti větví se totiž zaměřila právě na vytvoření přehledu módů, jimiž je $\mathrm{v}$ současné době sbíráno sedm vybraných šetření realizovaných jako součást Evropského statistického systému (na pěti z těchto šetření participuje

Projekt byl financován Eurostatem a veden Italským národním statistickým institutem (Istat); probíhal v letech 2017-2019. Př́mo na něm participovalo pět zemí (Itálie, Německo, Nizozemsko, Norsko, Rakousko), dalších pět zemí (Francie, Česká republika, Polsko, Finsko, Švédsko) jej podporovalo, ačkoli z dostupné dokumentace není zřejmé, v čem tato podpora spočívala. Projekt byl rozdělen do pěti částí (work packages/ WPs), dotazníkové šetření mezi národními statistickými úr̆ady představovalo WP1. Dále se projekt zaměǐil na efekt módu (WP2), organizaci výběrových šetření (WP3), designy smíšeného módu (WP4) a využívání mobilních zařízení (WP5). Většina témat však byla diskutována spíše v teoretické rovině. Více informací na stránkách Istatu (https:// www.istat.it/en/research-activity/international-research-activity/essnet-and-grants). 
naprostá většina evropských zemí). ${ }^{8}$ Údaje o využívaných módech a jejich kombinacích byly získány prostřednictvím online dotazníkového průzkumu, kterého se zúčastnilo 31 evropských statistických úřadů. Projekt se přitom zaměřil na sběr dat např́ič respondenty.

Tabulka 1: Přehled kombinací módů (nikoli sekvenci*) a typů designu** v pěti šetřeních pro jednotlivé participující země. Aktuální praxe dle dotazníkového šetření národních statistických úřadů pro projekt MIMOD. ČR zvýrazněna

\begin{tabular}{|c|c|c|c|c|c|c|c|}
\hline & LFS1 & LFS2+ & SILC1 & SILC2+ & EHIS & AES & ICT \\
\hline CAPI/PAPI & $\begin{array}{l}G R(C) \\
C Z(C) \\
P L(S)\end{array}$ & & $\begin{array}{l}C Z(C) \\
P L(S)\end{array}$ & $\begin{array}{l}C Z(C) \\
B G(C)\end{array}$ & $C Z(C)$ & $\begin{array}{l}C Z(C) \\
P L(S)\end{array}$ & $C Z(C)$ \\
\hline PAPI/CAWI & & & $G R(C)$ & $G R(C)$ & $\begin{array}{l}\mathrm{LU}(\mathrm{C}) \\
\mathrm{DE}(\mathrm{S})\end{array}$ & $B E(C)$ & $\begin{array}{l}\text { BE }(C) \\
\text { IT }(S)\end{array}$ \\
\hline CATI/CAPI & $\begin{array}{l}\text { FI (C) } \\
\text { LV }\end{array}$ & $\begin{array}{l}\text { AT } \\
\text { SI (C) } \\
\text { PT (C) } \\
\text { LT (C) } \\
\text { HR (C) } \\
\text { HU (C) } \\
\text { IE (C) } \\
\text { EE (C) } \\
\text { UK (C) IT (C) }\end{array}$ & $\begin{array}{l}\text { MT (C) } \\
\text { CH (C) } \\
\text { LV (C) } \\
\text { IT (C) }\end{array}$ & $\begin{array}{l}\text { AT } \\
\text { SI (C) } \\
\text { MT (C) } \\
\text { NO } \\
\text { CH (C) } \\
\text { CY (C) } \\
\text { IT (C) }\end{array}$ & & $\mathrm{EE}$ & UK \\
\hline CAPI/CAWI & & & $\mathrm{HU}(\mathrm{C})$ & $\mathrm{HU}(\mathrm{C})$ & $\begin{array}{l}\text { AT } \\
\text { SI } \\
\text { PT (S) } \\
\text { LT } \\
\text { NL (C) } \\
\text { EE (C) }\end{array}$ & $\begin{array}{l}\text { AT }(S) \\
\text { LT } \\
\text { HU (C) } \\
\text { FI }\end{array}$ & $\begin{array}{l}\text { SI (S) } \\
\text { PL (S) }\end{array}$ \\
\hline CATI/CAWI & $\begin{array}{l}\text { LU }(C) \\
\text { DK }\end{array}$ & $\begin{array}{l}\mathrm{LU}(\mathrm{C}) \mathrm{BE}(\mathrm{C}) \\
\mathrm{DK}\end{array}$ & $\begin{array}{l}\mathrm{NL}(\mathrm{C}) \\
\mathrm{DK}\end{array}$ & $\begin{array}{l}\mathrm{NL}(S) \\
\mathrm{DK}\end{array}$ & IC (S) & $\begin{array}{l}\mathrm{NL}(S) \\
\mathrm{NO}\end{array}$ & $\begin{array}{l}\text { SE (S) } \\
\mathrm{NL}(\mathrm{C}) \mathrm{CH}(\mathrm{C}) \\
\mathrm{EE}(\mathrm{C}) \\
\mathrm{FI}(\mathrm{S})\end{array}$ \\
\hline CATI/CAPI/CAWI & $\begin{array}{l}\mathrm{LT} \\
\mathrm{NL}\end{array}$ & LV & LT & $\begin{array}{l}\mathrm{LT} \\
\mathrm{EE} \\
\mathrm{LV}\end{array}$ & LV & $\begin{array}{l}\text { SI (S) } \\
\text { ES } \\
\text { LV }\end{array}$ & $\begin{array}{l}\text { PT (C) } \\
\text { LT } \\
\text { HR } \\
\text { ES } \\
\text { LV } \\
\end{array}$ \\
\hline CATI/PAPI/CAWI & & & & & SE (C) & & FR \\
\hline CATI/CAPI/PAPI & $\mathrm{DE}$ & $\begin{array}{l}\mathrm{DE}(\mathrm{C}) \mathrm{CZ}(\mathrm{C}) \\
\mathrm{PL}(\mathrm{S}) \mathrm{SK}\end{array}$ & & & & & \\
\hline
\end{tabular}

Zdroj: vlastní zpracování tabulek 10 a 15 z WP1 - Deliverable 2 a tabulek 1 a 2 z WP4 - Deliverable 1.

*více k sekvencím viz WP4 - Deliverable 1, str. 4 (https://www.istat.it/it/files//2011/07/WP4-deliverables.zip)

**C = souběžný (concurrent), $\mathrm{S}=$ sekvenční (sequential); neoznačené země jsou typ ,částečně souběžný, částečně sekvenční"

Pozn. 1: V rámci dotazníkového šetření nebylo rozlišeno mezi PAPI a PAP (tj. dotazováním s tazatelem a samovyplněním).

Pozn. 2: Není-li země pro dané šetření v tabulce uvedena, probíhá jeho sběr v současnosti jen jedním módem.

$8 \quad$ Konkrétně se jednalo o šetření Labour Force Survey (LFS), Survey on Income and Living Conditions (EU-SILC), European Health Interview Survey (EHIS), Adult Education Survey (AES), Survey on Information and Communication Technology (ICT), Household Budget Survey (HBS) a Harmonised European Time Use Survey (HETUS). 
Průzkum mimo jiné ukázal, že kombinování módů je v současné době běžnou praxí (pro detailní shrnutí viz Tabulka 1); ze všech zapojených zemích probíhal sběr dat konzistentně jedním módem pouze v Rumunsku (a to PAPI). Z údajů poskytnutých statistickými úřady též vyplynulo, že využívání smíšeného módu za posledních pět let vzrostlo - na vzestupu jsou zejména kombinace s CAWI, ačkoli je stále řada zemí, které dotazování online vůbec nevyužívají. Celkem bylo identifikováno osm možných kombinací, pět z nich s CAWI módem (první sloupec Tabulky 1); žádnou z nich však dle autorů nelze označit za „nejlepší“. Bylo také zjištěno, že v současné praxi převažuje souběžný design (Tabulka 1). Výsledky projektu též poukazují na to, že i přes hojné využívání smíšeného módu tento design či získaná data často nepodléhají rozsáhlejší metodologické a analytické reflexi (analýza kvality dat však nebyla součástí ani samotného projektu MIMOD). Módy též bývají kombinovány způsobem, který není zcela vhodný. Celkovým doporučením projektu MIMOD je revize metodologických pokynů ze strany Eurostatu - ty již neodpovídají ani praxi národních statistických úřadů, ani vývoji a možnostem nových technologií (Buelens et al. 2018; Murgia et al. 2018; Murgia et al. 2019).

\section{European Social Survey (ESS)}

ESS, v ČR také známé pod jménem Evropský sociální výzkum, je mezinárodní průřezové šetření sociálního chování a postojů evropských populací. ESS je od svého počátku v roce 2002 sbíráno tazateli v domácnostech, a to pomocí elektronických či papírových dotazníků. $Z$ dostupné dokumentace ${ }^{9}$ vyplývá, že přibližně do roku 2010 byly oba módy zastoupeny zhruba stejně - např. data páté vlny byla sbírána PAPI i CAPI shodně ve 14 zemích. Poté již pozorujeme postupný odklon od PAPI a zatím poslední, devátá vlna šetření byla ve všech participujících zemích sbírána již pouze prostřednictvím CAPI. Udržení praxe jediného face-to-face módu bylo zřejmě do značné míry ovlivněno experimenty se smíšeným módem, které probíhaly během první dekády nového milénia (tzv. Mixed Mode Methodology Programme). Šest experimentálních studií totiž ukázalo, že smíšený mód - ve srovnání se standardním postupem - nepřinesl v rámci ESS ani vyšší návratnost, ani lepší reprezentativitu vzorku (Martin 2011, s. 17-19; Villar a Fitzgerald 2017). Ačkoli s odstupem přibližně deseti let by jistě stálo za to experimenty zopakovat, nejnovější projekt - CRONOS - již cílí „jen“ na možnosti a limity CAWI. V rámci projektu byli britští, estonští a slovinští respondenti osmé vlny ESS přizváni k účasti na sérii krátkých dotazování online, jichž se pak účastnili po dobu 12 měsíců (respondentům bez adekvátního technického vybavení byl poskytnut tablet a připojení $\mathrm{k}$ internetu). Takto vytvořený panel sloužil $\mathrm{k}$ experimentům, pretestům a k dalšímu výzkumu (odměny, kontaktní mód a další). Výsledky tohoto projektu jsou v současné době analyzovány a nejsou veřejně dostupné (ESS N.d.).

9 Dostupné z rozcestníku na stránkách projektu https://www.europeansocialsurvey.org/data/ round-index.html. 
EVS, v ČR též jako Evropský výzkum hodnot, se stejně jako ESS dlouhodobě držel sběru dat jedním módem (dle země CAPI, PAPI; vzácně jiný mód; výjimečně v kombinacích) - částečně kvưli zajištění srovnatelnosti dat v čase, částečně z důvodu finančních a organizačních omezení, která limitují zavádění inovací (GGP 2018, s. 7). Přesto - a na rozdíl od ESS byl pro zatím poslední vlnu sběru dat (uskutečněnou v roce 2017) umožněn sběr smíšeným módem; oproti starším vlnám byla nově přidána možnost samovyplnění online dotazníku či dotazníku papírového k odeslání poštou (tj. CAWI a PAP). Země se při implementaci CAWI dotazníku řídily souborem obecnějších zásad (např. nezobrazovat ukazatel průchodu dotazníkem; umožnit vyplnění na chytrých telefonech; redukovat používání dlouhých baterií, a tedy omezit nutnost rolování), umožněn byl také tzv. matrix design, v jehož rámci respondenti dotazník vyplnili po částech (mini panel). Mód byl respondentům přidělen náhodně. Této možnosti využilo šest zemí: v Nizozemsku byla data sbírána kombinací CAPI a CAWI, ve Švýcarsku, Německu, Dánsku a Finsku CAPI a CAWI + PAP, na Islandu metodou CAPI + PAPI a CAWI + PAP (EVS 2017). Ani v tomto případě nejsou konečné výsledky experimentů ještě souhrnně publikovány; výsledky předběžné jsou však po všech stránkách slibné (Christmann et al. 2018) a pro další vlny šetření lze tedy očekávat postupný a koordinovaný přechod ke smíšenému módu či př́ímo k samovyplnění.

\section{Survey of Health, Ageing and Retirement in Europe (SHARE)}

SHARE zaměřené na populaci ve věku 50+ dlouhodobě kombinuje CAPI dotazování s papírovými samovyplňovacími dotazníky - nikoli ale „napříčc, nýbrž ,v rámci“ respondentů. Zavedení online módu zůstává doposud jen v rovině plánů. To je částečně dáno nižším internetovým pokrytím cílové populace i obsahem šetření, kde je sběr některých proměnných přímo závislý na prrítomnosti tazatele; částečně také nepř́liš povzbudivými výsledky experimentu z roku 2015 (GGP 2018, s. 7-8). Design kombinující CATI a CAWI testovaný v Nizozemsku měl vyřešit nedostatek finančních prostředků na realizaci šetření běžným způsobem, objevily se však nejen problémy technického rázu (např. padání serverů kvůli velikosti dotazníku), ale i problémy s návratností. Technická zpráva uvádí, že celý dotazník vyplnilo cca $50 \%$ všech oslovených respondentů a jen zhruba 40 \% respondentů panelových (de Bruijne et al. 2016, s. 10). Nicméně navzdory komplikacím byla data v Nizozemsku sbírána online i v roce 2017 (de Bruijne a Kalwij 2018, s. 3). Zajímavý kontrast k této dlouhodobě spíše konzervativní metodologii představuje rychlá reakce na koronavirovou pandemii, která na jaře roku 2020 znemožnila dokončení sběru dat osmé vlny standardním způsobem. Tato reakce mj. spočívala právě ve změně módu, a to z CAPI na CATI (Scherpenzeel et al. 2020, s. 218-219). Nejasné vyhlídky do blízké budoucnosti pak zrychlují plánovaný přechod ke smíšenému módu a jeho potenciálu reagovat např́ílad právě na potřebu omezení sociálního kontaktu se staršími osobami.

\section{International Social Survey Programme (ISSP)}

Průřezové šetření ISSP neboli Mezinárodní program sociálního výzkumu je příkladem raného použití smíšeného módu napříč zeměmi, napříč časem a napříč respondenty. V tomto projektu 
stř́dajícím různé tematické moduly použilo již v roce 2011 celkem devět z 32 zemí ke sběru dat více módů (Suzer-Gurtekin et al. 2018, s. 415). ISSP původně probíhalo jen korespondenčně, ale po zapojení zemí s nižší úrovní gramotnosti bylo povoleno osobní dotazování jako zásadní krok k široce pojatému smíšenému módu (de Leeuw et al. 2018, s. 388-389). Každá zapojená země má nyní relativní volnost v přizpůsobení podoby sběru dat vlastním podmínkám, kterou využívají $\mathrm{k}$ realizaci různých kombinací CAPI, CATI, CAWI, PAPI a CASI v rámci jedné vlny sběru (Suzer-Gurtekin et al. 2018).

\section{Generations and Gender Survey (GGS)}

V současnosti pravděpodobně nejvíce inovativní snahy o plošnou implementaci smíšeného módu s CAWI nalézáme v rámci projektu Generations and Gender Programme (GGP) a jeho šetření GGS. Inovace v tomto projektu jsou paradoxně umožněny diskontinuitou mezi prvním a druhým kolem sběru dat (GGP 2018). První a méně centralizované kolo panelového šetření proběhlo během první dekády nového milénia, kdy byly sesbírány (až) tři vlny dotazování. Začátek druhého kola započal v roce 2020 s použitím obměněného dotazníku a nově narekrutovaných panelových respondentů. Podobně jako u SHARE byla i v př́padě GGS data původně sbírána především kombinací osobního dotazování a samovyplnění (papírově či na počítači jako CASI), přičemž každý respondent participovat na obou módech. Naopak pro novou podobu šetření je nyní plánováno využití smíšeného módu naprríč respondenty. Design nového GGS, koncipovaný kolem strategie „push-to-web“, má podobu kombinace CAWI a CAPI/CASI pro dosběr respondentů, kteří se online dotazování nemohou z různých důvodů účastnit.

Funkčnost této strategie byla $\mathrm{v}$ předstihu testována prostřednictvím samostatného experimentu. „The GGP Push to Web Experiment“ se uskutečnil v letech 2017-2018 v Německu, Portugalsku a Chorvatsku, které měly reprezentovat heterogenitu evropského terénu. V každé zemi byl pak dále zvolen jeden region s obzvláště ztíženými podmínkami pro sběr dat online. Za účelem srovnání byli respondenti rozděleni do několika skupin; v kontrolní skupině byla data sesbírána obvyklým CAPI/CASI, v dalších alespoň dvou skupinách pak kombinací CAWI a CAPI/CASI (GGP 2018). Tyto experimenty prrinesly velmi slibné výsledky, zdokumentována byla ekvivalence CAPI a CAWI v rámci naprosté většiny položek nebo srovnatelná až vyšší míra návratnosti push-to-web designu ve srovnání s CAPI (Emery et al. 2019; Lück et al. 2019; Schumann 2019). Na základě předběžného testování i vývoje pandemické situace je tak v plánu rozsáhlé použití smíšeného módu obsahujícího CAWI, CAPI, CATI i PAP při ostrém sběru dat (GGP 2020).

\section{Smíšený mód a online sběry $v$ ČR?}

Česká republika je dlouhodobě zapojena do všech zmíněných evropských výzkumných infrastruktur, $v$ tuzemském kontextu však v současnosti chybí ucelenější přehled a diskuse metodologie těchto šetření a prŕpadných proměn (či naopak stability) v čase (srov. Buchtík 2012). Tabulka 2 tedy alespoň stručně shrnuje módy sběru dat ve všech vlnách šetření ESS, EVS, SHARE, ISSP a GGS. Je patrné, že pro českou praxi je dlouhodobě typický sběr dat jedním 
módem, přičemž ale sledujeme posun v čase od PAPI ke CAPI (tj. smíšený mód vzniká $\mathrm{v}$ čase). Méně častý smíšený mód napříč respondenty v jednom časovém bodě pak reprezentuje kombinace těchto dvou postupů, tj. tazatel při osobní návštěvě v domácnosti využívá bud'to papírového dotazníku, nebo dotazníku v notebooku. ${ }^{10}$ Míchání módo̊ je naopak zjevně standardem pro šetření Evropského statistického systému. Jde však zejména ,jen“"11 o kombinaci CAPI a PAPI (Tabulka 1).

Tabulka 2: Módy sběru dat ve všech vlnách vybraných evropských šetření: ČR

\begin{tabular}{|l|l|l|l|l|}
\hline ESS & EVS & SHARE & ISSP & GGS \\
\hline VIny 8-9 CAPI & VIna 5 CAPI, PAPI & Všechny vIny** CAPI/ & 2018-2019 CAPI, PAPI & VIna 2 CAPI/CASI† \\
VIna 7 CAPI, PAPI* & VIna 4 CAPI & PAP' & 2016-2017 CAPI & VIna 1 PAPI/PAP† \\
VIny 1-6 PAPI & VIna 3 PAPI & & 2015 CAPI, PAPI & \\
& VIna 2 PAPI & & 2014 CAPI & \\
& & & $1992-2013$ PAPI & \\
\hline
\end{tabular}

Zdroj: Vlastní zpracování dostupné dokumentace k jednotlivým projektům.

* dle dostupné dokumentace je ČR jediná země v celé historii ESS, která sbírala data dvěma módy současně

** s výjimkou vlny 8 zasažené pandemií

$\dagger$ „,V rámci“ respondentů

S konzervativnějším přístupem ke smíšenému módu se v ČR (v kontextu velkých šetření) pojí absence dotazování online (Tabulka 2). Tuzemské týmy se současně ani nezapojují do testování online sběrů a smíšeného módu (např. v rámci EVS nebo ESS). Důvody nejsou prozatím nikde explicitně rozvedeny; lze spekulovat, že se jedná např́iklad o nedostatečně rozvíjenou oblast metodologického výzkumu, horší finanční či časové zajištění velkých šetření, které neumožňuje testování inovací, anebo snahu o zachování kontinuity výzkumného nástroje $\mathrm{v}$ čase. Na druhou stranu dotazování online v domácím kontextu nezůstává zcela stranou aktuální praxe: CAWI figuruje v nabídce řady výzkumných agentur, jedná se však pouze o možnost dotazovat členy online panelů, nikoli o možnost dotazování náhodného vzorku respondentů. Tam, kde online dotazování probíhá mimo online panely, se typicky

10 Důvod, proč právě kombinace CAPI a PAPI není v dokumentaci explicitně diskutována, má pravděpodobně vazbu na praxi výzkumných agentur. Např́klad informace pro zájemce o pozici tazatele v agentuře Median jsou „Základní znalost práce s PC - pokud máte zájem o práci na notebooku“. Agentura STEM/MARK na svém webu nabízí možnost sběru dat prostřednictvím PAPI s komentářem, že: „Papírové dotazníky mají oproti elektronickým médiím několik výhod. [...] To, co v počítači zabere 20 obrazovek, se [...] může vejít na jeden list papíru. Díky tomu vypadá dotazník kratší a na respondenta působí lépe. Další výhodou je, že tazatel může s papírovým dotazníkem pracovat v terénu celý den, ale notebook se mu za pár hodin vybije.“ Na stránkách CVVM se pak dočteme, že , dotazování probíhá prostř̌ednictvím papírových dotazníků (PAPI) a v př́ípadě úspěšné spolupráce může tazatel pracovat na zapůjčených přenosných počítačích (CAPI)“.

11 Konkrétní kombinace CAPI a PAPI působí jako kombinace téměř totožných módů; ty se ale liší v ochotě různých skupin účastnit se výzkumu, délce vyplňování (Fuchs et al. 2000, s. 284), počtu chybějících hodnot nebo vyplňování citlivých otázek (Schräpler et al. 2010, s. 266), aniž by studie dospěly ke konzistentním zjištěním. 
jedná o dotazování specifických subpopulací osob s prŕístupem k internetu, např. šetření Eurostudent (také Ryšavý 2011).

Smíšený mód ve výběrových šetřeních realizovaný jinak nežli kombinací CAPI a PAPI a zvlášt' se zapojením CAWI - se zdá být v tuzemsku poměrně vzácný. V nabídce agentur jej nenalézáme. V Českém sociálněvědním datovém archivu (ČSDA) je možné dohledat několik $^{12}$ výzkumů se sběrem dat smíšeným módem s CAWI např́ič respondenty. Jde např́klad o projekty Umírání a péče o nevyléčitelně nemocné (2013) a Studie zaměřená na problematiku vnímání konce života a umírání prizmatem dříve vyslovených přání (2015), které byly oba sbírány kombinací CAWI (členové Českého národního panelu ve věku 15-59 let) a CAPI (osoby ve věku 59+); data byla následně spojena a vážena. Dále se jedná o šetření Analytici politiky v ústřední státní správě České republiky: praktiky, profesní hodnoty a identita (2013), kde bylo kombinováno osobní dotazování (CAPI, PAPI) a online dotazník. CAWI bylo také využito v rámci Českého panelového šetření domácností (CHPS), kde bylo online dotazování nabídnuto (náhodně vybraným) domácnostem, které odmítly návštěvu tazatele. Z projektové dokumentace vyplývá, že prostřednictvím CAWI se CHPS zúčastnilo přibližně $10 \%$ domácností (Kudrnáčová 2019, s. 21). Nutné je též zmínit Sčítání lidu, domů a bytů 2021, které se poprvé uskuteční online s papírovým dosběrem neinternetové populace.

\section{CAWI jako mód sběru dat při náhodných výběrech v ČR - vlastní testování}

Sběr dat přes internet je z výše zmíněných důvodů (cena, rychlost, flexibilita, omezený vliv a potřeba tazatele, rostoucí technologická vybavenost, využívání v mezinárodních šetřeních; viz de Leeuw a Hox 2011; Dillman et al. 2014; Tourangeau 2017) stále rostoucím trendem, kterému se nevyhne ani české prostředí. Předpokladem rozsáhlejšího využívání smíšeného módu založeného na CAWI v ČR je ovšem zodpovězení otázky, do jaké míry je v tuzemsku proveditelné online dotazování náhodného (ad hoc) vzorku respondentů. S online panely se totiž pojí řada problémů, a to zejména ,profesionalizace“ respondentů (Liu a Cernat 2018, s. 701). Závažný problém představuje také fakt, že online panely nereprezentují obecnou populaci, nýbrž pouze populaci uživatelů internetu. Tyto dvě populace se i přes narůstající ICT vybavenost a gramotnost stále ještě nepřekrývají (Herzing a Blom 2019, s. 405-406). Pro velká mezinárodní sociálněvědní šetření tedy online panely nejsou vhodné.

Na teoretické rovině lze usuzovat, že podmínky pro online sběry jsou i v obecné populaci vcelku vyhovující. Dle dat ČSU' ${ }^{13}$ v roce 2019 disponovalo počítačem i internetem zhruba $80 \%$ českých domácností. V $80 \%$ domácností vybavených počítačem se nacházel notebook a ve $40 \%$ tablet - členové domácností by tedy typicky měli mít dostatek soukromí na vyplnění dotazníku (ČSÚ 2019). V roce 2019 navíc 65 \% respondentů ve věku 16+ disponovalo telefonem s přístupem na internet. Využívání internetu je v ČR v současné době frekventované - v roce 2019 internet denně používalo 70 \% osob 16+. Vybavenost i užívání je nejvyšší

12 Uznáváme, že přehled nemusí být - s ohledem na velikost archivu - vyčerpávající.

13 Konkrétně výběrového šetření o využíání informačních a komunikačních technologií v domácnostech a mezi jednotlivci. 
mezi osobami mladšími a vzdělanějšími a snižuje se směrem ke skupinám starším a s nižším vzděláním (ČSÚ 2018, s. 47).

Tento vstupní předpoklad dobré připravenosti je však nezbytné oveřrit v praxi. Testování smíšeného designu $\mathrm{v}$ českém prostředí se aktuálně věnuje projekt TAČR řešený autory tohoto článku (2019-2021). V jeho rámci se zaměřujeme na výhody a limity sběru dat prostř̌ednictvím kombinace dotazování online a osobně s tazatelem, kdy CAWI je hlavním módem našeho designu a CAPI slouží $k$ dosběru neinternetové nebo jinak podreprezentované populace. Zajímá nás také, do jaké míry je možné sestavit pro online dotazování náhodný vzorek respondentů prostým navoláváním. Níže rozebereme výsledky pilotáže sociologického šetření, která proběhla v první polovině roku 2020. Účelem pilotáže bylo právě testovat efektivitu telefonické rekrutace pro dotazování online, stejně jako popsat charakteristiky získaného vzorku a podobu nasbíraných online dat. K zapojení CAPI módu dojde v další fázi projektu $\mathrm{v}$ roce 2021.

\section{Rekrutace pro CAWI: ochota k účasti, skutečná účast a charakteristiky vzorku}

Respondenti byli v rámci pilotáže pro online dotazování rekrutováni telefonicky. Mobilní telefonní čísla byla generována náhodně (metodou RDD), pevné linky byly doplněny na základě existující databáze spolupracující agentury. Na každé nezvedající volané číslo bylo voláno nejméně třikrát. $V$ př́ípadě zájmu o účast na šetření byli respondenti požádáni o sdělení základních demografických údajů a e-mailovou adresu, na kterou byla posléze zaslána zpráva $\mathrm{s}$ odkazem na dotazník $\mathrm{k}$ vyplnění na libovolném zařízení $\mathrm{s}$ prrístupem $\mathrm{k}$ internetu. Respondenti měli také možnost dotazník vyplnit „na několikrát“ dle svých časových možností, což byla strategie zapojená jako řešení (1) měkkých odmítnutí založených na nedostatku času i (2) relativně dlouhého dotazníku.

Výsledek rekrutace je shrnut $\mathrm{v}$ Tabulce 3 . Ta ukazuje, že většina obecné české populace je na online sběry připravena; chybějící „zázemí“ (nemá e-mail, nemá internet) neumožnilo účast 240 oslovených osob (tj. cca $10 \%$ ze všech zvedajících čísel). Častějším (deklarovaným) důvodem neúčasti tedy bylo prímé odmítnutí (52 \%) spíše než absence nutného vybavení. Kromě vysokého podílu odmítnutí pilotáž narazila také na značný podíl nevyplněných dotazníků: vyplnění prrislíbilo 752 respondentů, dokončených dotazníků bylo však jen 381 (tj. vyplnila zhruba polovina ${ }^{14}$ ). Zhruba třetina respondentů dotazník vůbec neotevřela, a to ani po e-mailové ${ }^{15}$ a telefonické urgenci. ${ }^{16}$ Není tak vyloučené, že v př́padě některých respondentů bylo uvedení e-mailu „únikovou variantou” z rekrutační situace.

Zjištění jsou tedy v souladu se zahraniční literaturou, podle níž bývá CAWI mód typický poměrně nízkou návratností (Callegaro et al. 2015, s. 137-143; Lozar Manfreda et. al. 2013).

14 Dalších 15 \% respondentů dotazník přinejmenším otevřelo, případně jej začalo vyplňovat, vyplňování však nedokončilo.

15 U pětiny dotazovaných jsme testovali vliv druhé e-mailové urgence a prodloužení doby dotazování, ale prínos pro návratnost byl zanedbatelný.

16 Zhruba polovina telefonických urgencí nebyla úspěšná - respondent nezvedl telefon; ani necelá pětina urgovaných, která slíbila dotazník vyplnit, tak neučinila. 
Navíc v testovaném designu nejde návratnost ani přesně spočítat, pokud nedokážeme spolehlivě odlišit nedovolaná čísla od neaktivních či např́iklad zaručit průchod e-mailů přes spamový filtr (Callegaro et al. 2015, s. 132-133). Důležitějším parametrem vzorku než míra návratnosti je přitom míra jeho odchýlení od cílové populace, a tyto údaje spolu nutně nesouvisejí (Antoun 2015, s. 105; Callegaro et al. 2015, s. 143-146; Chang a Krosnick 2009). Oba parametry vzorku by přitom mělo vylepšit zařazení dalšího vhodného módu. Konkrétně v našem designu sběru dat předpokládáme, že dosběr pro internetové šetření nedostupných/ neochotných respondentů osobním dotazováním nejen mírně zvýší návratnost, ale především pomůže pokrýt skupiny respondentů podreprezentované v CAWI.

Tabulka 3: Výsledek telefonické rekrutace metodou RDD (absolutně)

\begin{tabular}{|l|c|}
\hline Číslo neexistuje & 3816 \\
\hline Nedovoláno & 10406 \\
\hline Odmítnutí účasti & 1250 \\
\hline Nehodí se k dotazování & 414 \\
\hline a) nemá e-mail & 240 \\
\hline b) ostatní důvody (firma; neplnoletost) & 174 \\
\hline Přislíbení vyplnění & 752 \\
\hline a) dokončené dotazníky & 381 \\
\hline b) nedokončené dotazníky & 115 \\
\hline c) dotazník vůbec neotevren & 256 \\
\hline Telefonátů celkem & 16638 \\
\hline
\end{tabular}

Přes obecně nízkou ochotu k účasti není složení výsledného vzorku výrazně odchýleno od základního souboru (populace ČR ve věku 18+). Parametry celé populace 18+, respondentů souhlasících s vyplněním dotazníku a respondentů, kteří vyplnili celý dotazník, shrnuje Tabulka 4. Tyto výsledky současně ukazují, na které podreprezentované skupiny by mělo v průběhu rekrutace cílit nasazení dalšího módu a ostatních motivačních prvků. Vzorek byl v průměru o něco mladší než obecná populace; podreprezentovány byly osoby ve věku 65+, nadreprezentovány naopak osoby ve věku 35-54 let. Šetření se také častěji účastnily osoby vzdělanější. Pravděpodobně z důvodu vyšší účasti vzdělanějších osob byla více zastoupena sídla nad 100000 obyvatel a region Praha. Jinak bylo zastoupení krajů, obcí různých velikostí, věkových skupin i mužů a žen v podstatě vyvážené. Dotazníková data, ne př́liš překvapivě, indikují vliv „ICT selekce“, např. ve srovnání s výše uvedenými daty ČSÚ. Přístup k internetu mělo doma 94 \% respondentů a 90 \% používalo internet denně. K osobnímu užívání měli respondenti v průměru dvě zařízení, 87 \% disponovalo chytrým telefonem. Nejčastější přístup na internet byl právě prostřednictvím chytrého telefonu (48\% respondentů), $27 \%$ respondentů využívalo k přístupu na internet nejčastěji notebook, $18 \%$ stolní PC. 
Tabulka 4: Srovnání přislíbených a skutečných vyplnění s obecnou populací a populací 18+

\begin{tabular}{|c|c|c|c|}
\hline & Oficiální statistiky & $\begin{array}{l}\text { Přislíbena účast } \\
(\mathrm{N}=752)\end{array}$ & $\begin{array}{c}\text { Dokončené dotazníky } \\
(\mathrm{N}=381)\end{array}$ \\
\hline Podíl žen v populaci $18+1$ & 51 & 52 & 54 \\
\hline Průměrný věk $v$ populaci $18+2$ & Cca 50 & 44,5 & 47,7 \\
\hline Ženy $18+$ & Cca 51 & 45,3 & 48,5 \\
\hline Muži 18+ & Cca 48 & 43,7 & 46,9 \\
\hline \multicolumn{4}{|l|}{ Věkové skupiny (\%) } \\
\hline $18-24$ & 8 & 9 & 6 \\
\hline $25-34$ & 16 & 19 & 16 \\
\hline $35-44$ & 19 & 26 & 22 \\
\hline $45-54$ & 18 & 21 & 25 \\
\hline $55-64$ & 15 & 12 & 15 \\
\hline $65+$ & 25 & 13 & 17 \\
\hline Vzdělanostní skupiny ${ }^{3}$ (\%) & \multicolumn{3}{|c|}{$(25-64)$} \\
\hline ŽS & 6 & 4 & $2(N=7)$ \\
\hline SŠ bez maturity & 34 & 16 & 15 \\
\hline SŠ s maturitou (včetně VOŠ) & 38 & 47 & 40 \\
\hline VŠ & 22 & 34 & 43 \\
\hline Distribuce podle velikosti obce ${ }^{4}(\%)$ & (celá pop.) & \multicolumn{2}{|c|}{$(18+)$} \\
\hline$<5000$ & 39 & 30 & 29 \\
\hline $5000-19999$ & 18 & 21 & 22 \\
\hline $20000-49999$ & 12 & 13 & 10 \\
\hline $50000-99999$ & 8 & 7 & 7 \\
\hline$>100000$ & 22 & 29 & 32 \\
\hline Distribuce podle kraje' (\%) & \multicolumn{3}{|c|}{$(18+)$} \\
\hline Praha & 12 & 17 & 19 \\
\hline Středočeský & 13 & 12 & 10 \\
\hline Jihočeský & 6 & 6 & 6 \\
\hline Plzeňský & 6 & 4 & 5 \\
\hline Karlovarský & 3 & 3 & 3 \\
\hline Ústecký & 8 & 6 & 8 \\
\hline Liberecký & 4 & 4 & 4 \\
\hline Královéhradecký & 5 & 5 & 3 \\
\hline Pardubický & 5 & 5 & 7 \\
\hline Vysočina & 5 & 5 & 4 \\
\hline Jihomoravský & 11 & 12 & 12 \\
\hline Olomoucký & 6 & 6 & 5 \\
\hline Zlínský & 5 & 5 & 5 \\
\hline Moravskoslezský & 11 & 9 & 9 \\
\hline
\end{tabular}

* populace $18+$, květen/červen 2020, podíl z platných případů, všechny scénáře

${ }^{1}$ k 31. 12. 2019, Veřejná databáze ČSÚ

${ }^{2}$ k 31. 12. 2019, vlastní přibližný odhad na základě dat ČSÚ (poslední věková kategorie je $100+$ )

${ }^{3}$ populační data v r. 2018, Statistická ročenka ČR 2019 (https://www.czso.cz/csu/czso/24-vzdelavani-fvr4dq28wv) ${ }^{4}$ obecná populace (bez věkového omezení) k 31. 12. 2019, Veřejná databáze ČSÚ (tabulka „Velikostní skupiny obcí - počet obyvatel v obcích") 


\section{Metodologické otázky: použitá zařízení, zpưsob vyplňování, soukromí a multitasking}

Jak bylo shrnuto v první části textu, významnými problémy CAWI mohou být mj. mnohost zařízení, multitasking a nedostatek soukromí (Conrad et al. 2017; Couper a Peterson 2017). Naše data potvrzují nutnost věnovat zvýšenou pozornost designu dotazníku kvůli rozmanitosti zařízení (a zároveň rozmanitosti operačních systémů a internetových prohlížečů), na kterých jej respondenti vyplňují. Z respondentů našeho vzorku vyplnila dotazník na PC necelá třetina, na notebooku necelá polovina a necelá pětina použila k vyplnění chytrý telefon - shodně necelá pětina vyplňovala dotazník na zařízení s úhlopříčkou menší než 8 palců (cca $20 \mathrm{~cm}$ ). Celkem 93 \% respondentů vyplnilo celý dotazník na stejném zařízení a $95 \%$ respondentů by pro podobný dotazník využilo stejné zařízení i příště. Mód dotazování (CAWI) vyhovoval $96 \%$ respondentů; $3 \%(\mathrm{~N}=13)$ uvedla, že by př́íště raději vyplnila papírový dotazník. ${ }^{17}$ Respondenti používali různé nástroje vyplňování dotazníku: 74 \% využilo myš, 12 \% fyzickou klávesnici, 24 \% dotykový displej a jednotky př́ípadů virtuální klávesnici nebo elektronickou tužku. Srovnání délky textu u nejrozsáhlejší otevřené otázky v tomto ohledu ukázalo, že uživatelé myši a/nebo klávesnice napsali o 58 \% více znaků než uživatelé dotykových př́strojů (což je v souladu se zahraničními zjištěními, např. Tourangeau et al. 2017). Při programování dotazníku je také třeba vzít v potaz orientaci zařízení, naše data ale ukazují, že to není jednoduchý úkol. Mezi respondenty vyplňujícími pomocí tabletu nebo chytrého telefonu nebyla zřejmá žádná převažující tendence; 48 \% drželo zařízení na šířku, 46 \% na výšku a 6 \% střídavě na výšku i na šířku.

Problém nedostatečného soukromí nebo nedostatečné pozornosti se v datech objevil spíše v malé míře. Většina našich respondentů (81\%) uvedla, že dotazník vyplňovala doma ( 16 \% vyplňovalo v práci) a zhruba dvě třetiny uvedly, že to bylo bez přítomnosti jiných osob v bezprostředním okolí. Ovšem ani respondenti, v jejichž bezprostředním okolí se jiní lidé nacházeli, nedeklarovali vliv tohoto faktoru na způsob vyplnění dotazníku. Téměř všichni respondenti uvedli, že dotazník vyplnili pečlivě, 81 \% uvedlo, že jej vyplnili zcela pravdivě a $18 \%$ spíše pravdivě. Co se týče tzv. multitaskingu, $27 \%$ respondentů uvedlo, že se při vyplňování dotazníku věnovali i nějaké jiné činnosti. Z odpovědí na otevřenou otázku o povaze těchto činností vyplývá, že se většinou jednalo o konzumaci potravin, sledování TV, poslech hudby či vyřizování e-mailů. Všechna tato zjištění jsou samozřejmě omezena tím, že jsou založena na deklaracích respondentů a naše další šetření bude testovat jejich souvislost s mírou sociální žádoucnosti.

\section{Diskuse a závěr}

Shrneme-li tyto dílčí poznatky, pak lze konstatovat, že základní vstupní podmínky pro implementaci smíšeného módu s výrazným podílem online dotazování jsou v domácím kontextu vyhovující - a to i pro náhodné výběry, tj. mimo online panely. Vybavenost populace technickým zázemím a internetem je vysoká, samostatné vyplnění online dotazníků se pro

17 Preference módu, ve kterém dotazování probíhá, není nic nového a je spojeno s určitou mírou samovýběru (Dillman et al. 2014, s. 421-426). Zde se ale objevil překvapivě nulový zájem o varianty CAPI a CATI. 
respondenty s dostatečnou mírou motivace nezdá být problémem. Prvotní údaje o nákladnosti CAWI v rámci náhodného vzorku jsou také poměrně povzbudivé. ${ }^{18} \mathrm{Na}$ druhou stranu je však CAWI (přinejmenším při telefonické rekrutaci) charakteristické nízkou návratností, resp. výrazným rozdílem mezi počtem přislíbených a dokončených dotazníků. CAWI samo o sobě nemůže generovat reprezentativní vzorek respondentů, a navíc nabízí jednoduchý „únik“ z dotazovací situace, což je ve spojení s nižší úrovní motivace typickým prvkem samovyplňovacích módů (de Leeuw a Hox 2011, s. 66-67; Smyth a Pearson 2011). Vše zmíněné odpovídá mnoha zjištěním ze zahraničí a představuje jeden $\mathrm{z}$ hlavních důvodů využití CAWI v kombinaci s dalším módem, nikoli samostatně.

Naše data nadto ukazují, že online mód má řadu specifických charakteristik, které mohou být potenciálně problematické a jimž bude muset být $\mathrm{v}$ rámci smíšených designů věnována zvýšená pozornost. I čeští online respondenti mohou být při vyplňování méně soustředění kvůli náchylnosti $\mathrm{k}$ multitaskingu. $\mathrm{Z}$ důvodu mnohosti zařízení a nemalého zastoupení chytrých telefonů také může variovat podoba vizuální informace (tj. zobrazení dotazníku), což je potenciálním problémem nejen v rámci CAWI, ale i v rámci např. CASI při dotazování „tvárí v tváŕr“. Další testování smíšeného módu se tedy bude muset zaměřit např́íklad na design dotazníku srovnatelného napříč módy, motivaci $\mathrm{k}$ vyplnění CAWI, optimalizaci rekrutace včetně zvážení jiných opor výběru, efekt módu a efekt zařízení, a co je nejdůležitější, kvalitu a srovnatelnost výsledných dat. Experimenty v rámci velkých mezinárodních výzkumných infrastruktur se pro takové testování - díky „zázemí“, sdílenému know-how, předem specifikovanému designu a možnosti mezinárodního srovnání i inspirace - jeví jako dobrá př́ležitost pro zapojení českých výzkumných týmů. Nezanedbatelnou roli by však mělo hrát i „nezávislé“ testování na národní úrovni, které bude vycházet ze specifik českého terénu.

Př́kladem testování na národní úrovni je představená pilotáž, která odhalila řadu problematických aspektů, jež je nutné řešit $\mathrm{v}$ rámci následujícího šetření i dalších studií podobného formátu. Krom už rozebraného podreprezentování některých skupin a nízké návratnosti, které by měly být alespoň částečně adresovány zapojením osobního dotazování a dalších motivačních prvků, se objevily alespoň tři témata $\mathrm{k}$ další diskusi. Za prvé, RDD nemusí být nejefektivnější metodou rekrutace pro online dotazování a měla by být experimentálně srovnána $\mathrm{s}$ alternativami jako stratifikovaný výběr domácností nebo náhodná procházka. Tyto varianty by měly být srovnány z hlediska ceny, kvality vzorku i kvality výsledných dat. Za druhé, $\mathrm{v}$ rámci vývoje designu pracujeme s otázkou dosud nerealizovaného ověření identity vyplňující osoby. Tento prvek se jeví důležitějším pro sběr přes online panely (Craig et al. 2013, s. 1-2; Jones et al. 2015, s. 688), ale sdružení ESOMAR (2015, s. 6) jej doporučuje i pro nepanelové online sběry, přestože na stejném místě cituje studii o pochybném až kontraproduktivním př́nosu tohoto kroku pro kvalitu dat (Courtright a Pashupati 2014). Za třetí, testování sběru dat záměrně pracovalo s dlouhým dotazníkem (asi 50 minut), a přitom tato délka může být kvůli nevhodnosti pro CAWI jednou z příčin nízké návratnosti. Literatura $\mathrm{k}$ tomuto tématu zmiňuje negativní vliv délky dotazníku především pro vyplňování na mobilních zařízeních (Toepoel a Lugtig 2018, s. 3) a dotazníky delší než 20 minut jako nevhodné

18 Komplexní finanční srovnání tohoto designu s alternativou osobního dotazování ale budeme schopni vyhodnotit až v další fázi projektu. 
pro CAWI (Callegaro et al. 2015, s. 102; ESOMAR 2015, s. 10). Texty zároveň upozorňují na neutrální vliv délky i velmi rozsáhlých dotazníků za určitých podmínek (Callegaro et al. 2015, s. 101-102; Christmann et al. 2018). My jsme se tyto podmínky pokusili naplnit a) využitím co nejvíce motivačních prvků a b) ukládáním průběžného vyplňování, ke kterému se respondenti můžou kdykoli vrátit.

Nejperspektivnější variantou smíšeného módu je dotazování online (CAWI) s dosběrem neinternetové populace jiným způsobem. Atraktivita tohoto řešení dále roste v kontextu narůstající technologické gramotnosti a vybavenosti populace, nových softwarových možností pro kombinaci módů, rostoucích nákladů na práci tazatelů i telefonních operátorů a klesající ochoty účastnit se tradičních módů sběru. Jak článek ilustruje, prakticky všechna nejvýznamnější sociálněvědní šetření mezinárodního rozsahu přecházejí na smíšený mód s rostoucí rolí CAWI, anebo tyto možnosti alespoň testují. Řada prvků vyvinutých v některých zemích (opora výběru, funkční a legislativně proveditelná forma odměn, míra a způsob používání komunikačních technologií) však může fungovat odlišně v českém prostředí (Martin 2011, s. 21-22; Villar a Fitzgerald 2017, s. 269-270), a proto je nutné testování nových forem dotazování v tuzemském kontextu.

Dle dílčích zjištění této studie má smíšený mód perspektivu i v českém prostř̌edí; technická stránka použití smíšeného módu postaveného na CAWI je realizovatelná a další úsilí je třeba věnovat metodologickému vývoji této podoby dotazování a edukaci ohledně jejích možností a specifik nasbíraných dat. V neposlední řadě je třeba zdůraznit potřebu zvažovat využití více módů (nebo pozdější přechod na jiný mód) již ve fázi tvorby dotazníku nebo jeho položek. Tyto nástroje by měly být vyplnitelné nejen v různých módech, ale i přes různá zařízení, na což některá dlouhodobější šetření i softwarová řešení v současnosti narážejí. Zlatým standardem se v tomto ohledu stává unimode design při tvorbě dotazníků (Bethlehem a Biffignandi 2011, s. 249) a responzivní web design v oblasti softwaru pro sběr dat (Callegaro et al. 2015, s. 201). K řešení nadále zůstávají otázky vlivu smíšeného módu na kvalitu dat, míry srovnatelnosti odpovědí napříč módy nebo vlivu změny módu na srovnatelnost $\mathrm{v}$ čase. $\mathrm{V}$ této stále nové a dynamicky se rozvíjející oblasti je tak zapotřebí dalšího testování a metodologických experimentů, $\mathrm{k}$ čemuž bychom chtěli naše čtenářky a čtenáře důrazně povzbudit.

\section{Literatura}

ANTOUN, Christopher. 2015. „Who Are the Internet Users, Mobile Internet Users, and Mobile-Mostly Internet Users? Demographic Differences across Internet-Use Subgroups in the U.S.“ Pp. 99-117 in Daniele TONINELLI, Robert PINTER, Pablo DE PEDRAZA (eds.). Mobile Research Methods: Opportunities and Challenges of Mobile Research Methodologies. London: Ubiquity Press.

BETHLEHEM, Jelke a Silvia BIFFIGNANDI. 2011. Handbook of Web Surveys (Vol. 567). Hoboken, NJ: John Wiley \& Sons.

BOSNJAK, Michael, Robert BAUER a Kai W. WEYANDT. 2018. „Mixed Devices in Online Surveys: Prevalence, Determinants, and Consequences." Pp. 53-65 in Axel THEOBALD (ed.). Mobile Research. Wiesbaden: Springer Gabler. 
BUELENS, Bart, Jan A. VAN DEN BRAKEL a Barry SCHOUTEN. 2018. Current Methodologies to Deal with Mode Effects and Mode Bias in Mixed-Mode Designs (Project MIMOD, WP2, Deliverable 1). Cit. 20. ř́jna 2020 (https://www.istat.it/it/files//2011/07/WP2-deliverables.zip).

BUCHTÍK, Martin. 2012. „Smíšené módy sběru dat v kvantitativním sociálněvědním výzkumu.“ Data a výzkum-SDA Info 6(2): 129-149.

CALLEGARO, Mario, Katja Lozar MANFREDA a Vasja VEHOVAR. 2015. Web Survey Methodology. London: Sage.

CONRAD Frederick G., Mick P. COUPER, Roger TOURANGEAU a Chan ZHANG. 2017. „Reducing Speeding in Web Surveys by Providing Immediate Feedback.“ Survey Research Methods 11(1): 45-61.

COUPER, Mick P. 2017. „New Developments in Survey Data Collection.“ Annual Review of Sociology 43: $121-145$.

COURTRIGHT, Melanie a Kartik PASHUPATI. 2014. „The Impact of Digital Fingerprinting and Identity Verification on Data Quality.“ Journal of Advertising Research 54(3): 263-269.

COUPER, Mick P. a Gregg J. PETERSON. 2017. „Why Do Web Surveys Take Longer on Smartphones?“ Social Science Computer Review 35(3): 357-377.

CRAIG, Benjamin M., Ron D. HAYS, A. Simon PICKARD, David CELLA, Dennis A. REVICKI a Bryce B. REEVE. 2013. „Comparison of US Panel Vendors for Online Surveys.“ Journal of Medical Internet Research 15(11): e260.

ČSÚ. 2018. Informační společnost v číslech 2018. Česká republika a EU. Praha: Český statistický úřad. Cit. 15. dubna 2020 (https://www.czso.cz/documents/10180/61601892/061004-18.pdf/5c26ca38-ec13-4aef-8fca-d30ae38291f3?version=1.1).

ČSÚ. 2019. „Využívání informačních a komunikačních technologií v domácnostech a mezi jednotlivci“. Tabulky 1.1, 1.3, 3.1, 5.1. Cit 25. září 2020 (https://www.czso.cz/csu/czso/vyuzivani-informacnich-a-komunikacnich-technologii-v-domacnostech-a-mezi-jednotlivci-2019).

DE BRUIJNE, Marika a Adriaan KALWIJ. 2018. SHARE-NL CAWI Data Collection for Wave 7. Tilburg: CentERdata.

DE BRUIJNE, Marika, Boukje CUELENAERE, Josette JANSSEN a Marije OUDEJANS. 2016. SHARE-NL: CAWI + CATI Data Collection for Wave 6. Tilburg: CentERdata.

DE LEEUW, Edith D. a Vera TOEPOEL. 2018. „Mixed-Mode and Mixed-Device Surveys.“ Pp. 5161 in David L. VANNETTE a Jon A. KROSNICK (eds). The Palgrave Handbook of Survey Research. Cham: Palgrave Macmillan.

DE LEEUW, Edith D., Z. Tuba SUZER-GURTEKIN a Joop J. HOX. 2018. „,The Design and Implementation of Mixed-mode Surveys.“ Pp. 387-408 in Timothy P. JOHNSON, Beth-Ellen PENNELL, Ineke A. L. STOOP a Brita DORER (eds.). Advances in Comparative Survey Methods: Multinational, Multiregional, and Multicultural Contexts (3MC). New York: John Wiley \& Sons.

DE LEEUW, Edith. D. a Joop J. HOX. 2011. „Internet Surveys As Part Of A Mixed-Mode Design.“ Pp. 45-76 in Marcel DAS et al. (eds.). Social and Behavioral Research and the Internet: Advances in Applied Methods and Research Strategies. New York: Routledge/ Taylor \& Francis Group.

DILLMAN, Don A., Jolene D. SMYTH a Leah M.CHRISTIAN. 2014. Internet, Phone, Mail, and Mixed-Mode Surveys: The Tailored Design Method. Hoboken, NJ: John Wiley \& Sons.

EMERY, Tom, Susanna CABAÇO a Luisa FADEL. 2019. The Generations \& Gender Survey: Breakoffs In A Very Long Online Survey. European Survey Research Association Conference, Zagreb.

ESOMAR. 2015. „ESOMAR/GRBN Guideline for Online Sample Quality.“ Cit 23. února 2021 (https:// www.esomar.org/what-we-do/code-guidelines/esomargrbn-guideline-on-online-sample-quality).

ESS. N.d. „CROss-National Online Survey (CRONOS) Panel.“ Cit. 15. záŕí 2020 (https:// www.europeansocialsurvey.org/methodology/methodological_research/modes_of_data_collection/ cronos.html). 
EVS. 2017. „European Values Study 2017. Mixed-Mode Strategy Guidelines: Recommendations and Guidelines for the Implementation of the CAWI Version of the EVS 2017.“ Dostupné z archivu GESIS. Cit. 15. záŕí 2020 (https://dbk.gesis.org/dbksearch/download.asp?id=65218).

FUCHS, Marek, Mick COUPER a Sue Ellen HANSEN. 2000. „Technology Effects: Do CAPI or PAPI Interviews Take Longer?“ Journal of Official Statistics 16(3): 273-286.

GGP. 2018. „GGP Technical Case and E-Needs, Deliverable 2.1 of the GGP-EPI Project Funded under the European Union's Horizon 2020 Research and Innovation Programme GA No: 739511.“ Cit. 2. března 2019 (www.ggp-i.org/ggpepi).

GGP. 2020. „Country Reports - GGP Council of Partners.“ The Hague: Netherlands Interdisciplinary Demographic Institute.

GUMMER, Tobias a Joss ROßMANN. 2015. „Explaining Interview Duration in Web Surveys: A Multilevel Approach.“ Social Science Computer Review 3(2): 217-234.

HERZING, Jessica M. a Annelies G. BLOM. 2019. „The Influence Of a Person's Digital Affinity on Unit Nonresponse nd Attrition in an Online Panel." Social Science Computer Review 37(3): 404-424.

HOX, Joop, Edith D. DE LEEUW a Thoma KLAUSCH. 2017. „Mixed Mode Research: Issues in Design and Analysis." Pp. 511-530 in Paul BIEMER et al. (eds.). Total Survey Error in Practice: Improving Quality in the Era of Big Data. New York: Wiley.

CHANG, LinChiat a Jon A. KROSNICK. 2009. „National Surveys Via RDD Telephone Interviewing Versus the Internet: Comparing Sample Representativeness and Response Quality.“ Public Opinion Quarterly 73(4): 641-678.

CHRISTMANN, Pablo, Tobias GUMMER, Sascha HÄHNEL a Christof WOLF. 2018. Probability Based Mixed-Mode Surveys: Experimental Evidence from the EVS-Germany. Natcen-ESS ERIC-City Methodology Seminar Series.

CHYLÍKOVÁ, Johana. 2011. „Úvod do problematiky výzkumu citlivých témat ve výběrových šetřeních.“ Data a výzkum - SDA Info 5(2): 185-203.

JONES, Michael S., Lisa A. HOUSE a Zhifeng GAO. 2015. „Respondent Screening and Revealed Preference Axioms: Testing Quarantining Methods for Enhanced Data Quality in Web Panel Surveys.“ Public Opinion Quarterly 79(3): 687-709.

KREJČÍ, Jindřich. 2008. Kvalita sociálněvědních výběrových šetření v České republice. Praha: Sociologické nakladatelství (SLON).

KUDRNÁČOVÁ, Michaela. 2019. České panelové šetřeni domácností: Dokumentace $k$ datům, vlna 1 (2015) - vlna 4 (2018). Praha: Sociologický ústav AV ČR.

LIU, Mingnan a Alexandru CERNAT. 2018. „Item-by-Item Versus Matrix Questions: A Web Survey Experiment.“ Social Science Computer Review 36(6): 690-706.

LOZAR MANFREDA, Katja, Nejc BERZELAK a Vasja VEHOVAR. 2013. Paradata Insight into Survey Response Behaviour: An Analysis of a Set of Hosted Web Surveys. General Online Research Conference (GOR), Mannheim, Germany.

LÜCK, Detlev, Almut SCHUMANN, Robert NADERI, Martin BUJARD, Tom EMERY, Susana CABAÇO, Peter LUGTIG a Vera TOEPOEL. 2019. Improving Data-Quality in the GGS: Are Modifications in the Questionnaire and Survey Design in the Generations and Gender Survey Able to Resolve Measurement Errors? European Survey Research Association Conference, Zagreb.

LYNN, Peter. 2020. „Evaluating Push-To-Web Methodology for Mixed-Mode Surveys Using Address-Based Samples.“ Survey Research Methods 14(1): 19-30.

MARTIN, Peter. 2011. „A Good Mix? Mixed Mode Data Collection and Cross-National Surveys.“ Ask. Research \& Methods 20: 5-26.

MURGIA, Manuela et al. 2019. Methodological Report: Mixed-Mode Strategies for Social Surveys: How to Best Combine Data Collection Modes (Project MIMOD, WP1, Deliverable 2). Cit. 15. zárí 2020 (https://www.istat.it/it/files//2011/07/WP1-deliverables.zip). 
MURGIA, Manuela, Martina LO CONTE, Dag F. GRAVEM. 2018. Report on MIMOD Survey on the State of the Art of Mixed Mode for EU Social Surveys (Project MIMOD, WP1, Deliverable 1). Cit. 15. záŕí 2020 (https://www.istat.it/it/files//2011/07/WP1-deliverables.zip).

RYŠAVÝ, Dušan. 2011. „Úskalí on-line dotazování při měření postojů vysokoškoláků a pracovníků vysokých škol.“ Data a výzkum-SDA Info 5(1): 85-103.

SELKÄLÄ, Arto a Mick. P. COUPER. 2018. „Automatic Versus Manual Forwarding in Web Surveys.“ Social Science Computer Review 36(6): 669-689.

SCHERPENZEEL, Annette, Kathrin AXT, Michael BERGMANN, Salima DOUHOU, Andrea OEPEN, Gregor SAND, Karin SCHULLER, Stephanie STUCK, Melanie WAGNER a Axel BÖRSCHSUPAN. 2020. „Collecting Survey Data among the 50+ Population during the COVID-19 Outbreak: The Survey of Health, Ageing and Retirement in Europe (SHARE).“ Survey Research Methods 14(2): 217-221.

SCHRÄPLER, Jörg-Peter, Jürgen SCHUPP a Gert G. WAGNER. 2010. „Changing from PAPI to CAPI: Introducing CAPI in a Longitudinal Study.“ Journal of Official Statistics 26(2): 239-269.

SCHUMANN, Almut. 2019. Which Incentive Works Best? Findings from a Push-to-Web Experiment in the GGP Context in Germany. European Survey Research Association Conference, Zagreb.

SMYTH, Jolene D. a Jennie E. PEARSON. 2011. „Internet Survey Methods: A Review of Strengths, Weaknesses, and Innovations.“ Pp. 11-44 in Marcel DAS et al. (eds.). Social and Behavioral Research and the Internet: Advances in Applied Methods and Research Strategies. New York: Routledge/ Taylor \& Francis Group.

STRUMINSKAYA, Bella, Kai WEYANDT a Michael BOSNJAK. 2015. „The Effects of Questionnaire Completion Using Mobile Devices on Data Quality. Evidence from a Probability-Based General Population Panel." Methods, Data, Analyses 9(2): 261-292.

SUZER-GURTEKIN, Z. Tuba, Richard VALLIANT, Steven G. HEERINGA a Edith D. de LEEUW. 2018. „Mixed-mode Surveys: Design, Estimation, and Adjustment Methods.“ Pp. 409-430 in Timothy P. JOHNSON, Beth-Ellen PENNELL, Ineke A. L. STOOP a Brita DORER (eds.). Advances in Comparative Survey Methods: Multinational, Multiregional, and Multicultural Contexts (3MC). New York: John Wiley \& Sons.

TOEPOEL, Vera a Peter LUGTIG. 2015. „Introduction: Online Surveys are Mixed-Device Surveys. Issues Associated with the Use of Different (Mobile) Devices in Web Surveys." Methods, Data, Analyses 9(2): 155-162.

TOEPOEL, Vera a Peter LUGTIG. 2018. „Modularization in an Era of Mobile Web: Investigating the Effects of Cutting a Survey into Smaller Pieces on Data Quality." Social Science Computer Review [online first].

TOURANGEAU, Roger. 2017. „Mixing Modes: Tradeoffs among Coverage, Nonresponse, and Measurement Error." Pp. 115-132 in Paul BIEMER et al. (eds.). Total Survey Error in Practice: Improving Quality in the Era of Big Data. New York: Wiley.

TOURANGEAU, Roger, Aaron MAITLAND, Gonzalo RIVERO, Hanyu SUN, Douglas WILLIAMS a Ting YAN. 2017. „Web Surveys by Smartphone and Tablets: Effects on Survey Responses.“ $P u$ blic Opinion Quarterly 81(4): 896-929.

VILLAR, Ana a Rory FITZGERALD. 2017. „Using Mixed Modes in Survey Data Research: Results from Six Experiments.“ Pp. 273-310 in Michael J. BREEN (ed.). Values and Identities in Europe: Evidence from the European Social Survey. London: Routledge. 


\section{Autoři}

Barbora Hubatková je odbornou pracovnicí Katedry sociologie Fakulty sociálních studií Masarykovy univerzity v Brně (Joštova 10). K jejím výzkumným zájmům patří rodina, stárnutí, vzdělání a metodologie smíšeného módu.

Kontakt:220208@mail.muni.cz

Martin Lakomý je sociologem na Katedře sociologie Masarykovy univerzity v Brně (Joštova 10). Věnuje se především zasazování populačního stárnutí do společenského kontextu, vývoji hodnot a jejich vlivu na lidské chování a v neposlední řadě metodologii společenských věd se zaměřením na smíšený mód.

Kontakt: lakomy@fss.muni.cz 